\title{
POSTHARVEST QUALITY OF FEIJOA FLOWERS TREATED WITH DIFFERENT PRESERVATIVE SOLUTIONS AND 1-METHYLCYCLOPROPENE ${ }^{1}$
}

\author{
ALEXANDRA GOEDE DE SOUZA², CASSANDRO VIDAL TALAMINI DO AMARANTE ${ }^{3}$, \\ CRISTIANO ANDRÉ STEFFENS ${ }^{3}$, THALITA DAL TOÉ BENINCÁ ${ }^{4}$, \\ MARCELA PADILHA ${ }^{4}$
}

\begin{abstract}
This study was carried out to assess the postharvest quality preservation of feijoa (Acca sellowiana Berg) flowers in response to treatments with different preservative solutions and 1-methylcyclopropene (1-MCP). Recently opened feijoa flowers were harvested in the morning (between $8 \mathrm{~h}$ and $10 \mathrm{~h}$ ) and immediately after pulsed with preservative solutions of salicylic acid, ascorbic acid and sucrose, all at doses of 0 (control), 2, 5 or 10\%, and treated with 1-MCP at doses of 0 (control), 250, 500 or $1,000 \mathrm{~nL} \mathrm{~L}^{-1}$. Each trial with preservative solutions or 1-MCP treatment was a distinct experiment conducted in a completely randomized design with four replicates, each replicate with four flowers. After the treatment, the flowers were stored for 12 days at $10 \pm 1{ }^{\circ} \mathrm{C}$ and $85 \pm 5 \%$ RH. At every two-days intervals the flower petals were visually evaluated for wilting and darkening according to a hedonic scale varying from 1 (less intense) to 5 (more intense). Petal color was ranked from 1 (intense pink) to 5 (white). The 1-MCP at 500 $\mathrm{nL} \mathrm{L}^{-1}$ and the salicylic acid (regardless of the dose) delayed the changes of petal color for up to eight and six days of storage, respectively. Flowers treated with salicylic acid, 1-MCP or ascorbic acid had a more substantial delay in petal wilting. Flowers treated with salicylic acid had wilting rank of 2 after six days of storage when treated with doses of $5 \%$ or $10 \%$, and after eight days when treated with the dose of $2 \%$, while flowers treated with 1-MCP at 500 and $1,000 \mathrm{~nL} \mathrm{~L}^{-1}$ and ascorbic acid at $2 \%$ and $5 \%$ had wilting rank of 2 after four days of storage. The most substantial delay of petal darkening (until the fourth day of storage) was achieved with 1-MCP at $500 \mathrm{~nL} \mathrm{~L}^{-1}$.
\end{abstract}

Index terms: Acca sellowiana Berg., edible flower, petal wilting, petal browning, petal color.

\section{QUALIDADE PÓS-COLHEITA DE FLORES DE GOIABEIRA-SERRANA TRATADAS COM SOLUÇÕES CONSERVANTES E 1-METILCICLOPROPENO}

RESUMO - O objetivo deste trabalho foi avaliar a manutenção da qualidade pós-colheita de flores de goiabeira-serrana (Acca sellowiana Berg), em resposta ao tratamento com soluções conservantes e 1-metilciclopropeno (1-MCP). As flores recém-abertas de goiabeira-serrana foram colhidas no início da manhã (entre 8 e 10 h) e submetidas a "pulsing" com soluções conservantes de ácido salicílico, ácido ascórbico e sacarose, todas nas doses de 0 (testemunha), 2, 5 e 10\%, e aplicação de 1-MCP nas doses de 0 (testemunha), 250; 500 e $1.000 \mathrm{~nL} \mathrm{~L}^{-1}$. Cada ensaio com solução conservante ou de tratamento com 1-MCP consistiu em experimento distinto, segundo delineamento experimental inteiramente casualizado, com quatro repetições, cada repetição com quatro flores. Após o tratamento, as flores foram armazenadas durante 12 dias a $10 \pm 1{ }^{\circ} \mathrm{Ce}$ $85 \pm 5 \%$ UR, e as pétalas avaliadas visualmente, em intervalos de dois dias, quanto a murcha e escurecimento, em uma escala de 1 (pouco acentuado) a 5 (muito acentuado), e de cor, numa escala de 1 (rosa intenso) a 5 (branco). O 1-MCP na dose de $500 \mathrm{~nL} \mathrm{~L}^{-1}$ e o ácido salicílico, independentemente da dose, prolongaram a manutenção da cor das pétalas por oito e seis dias de armazenamento, respectivamente. A murcha das pétalas também foi menor nos tratamentos com ácido salicílico, 1-MCP ou ácido ascórbico; flores tratadas com ácido salić́lico passaram para 2 na escala evolutiva no sexto dia nas doses de 5 e $10 \%$, e no oitavo dia na dose de 2\%; enquanto em flores tratadas com 1-MCP nas doses de 500 e $1000 \mathrm{~nL} \mathrm{~L}^{-1} \mathrm{e}$ ácido ascórbico nas doses de 2 e $5 \%$, isto ocorreu no quarto dia de armazenamento. O maior retardo no escurecimento das pétalas (até o quarto dia de armazenamento) foi obtido com $500 \mathrm{~nL} \mathrm{~L}^{-1}$ de 1-MCP.

Termos para indexação: Acca sellowiana Berg., flor comestível, murchamento de pétalas, escurecimento de pétalas, cor de pétalas.

\footnotetext{
${ }^{1}$ (Paper 100-15). Received April 16, 2015. Accepted September 09, 2015.

${ }^{2}$ Agronomist, Graduate student in Plant Production, Center for Agricultural and Veterinarian Sciences (CAV), Santa Catarina State University (UDESC). Av. Luiz de Camões, 2090, CEP 88520-000, Lages-SC. E-mail: alexandra.goede@gmail.com

${ }^{3} \mathrm{PhD}$, Productivity Researcher at CNPq, Professor of the Department of Agronomy, CAV / UDESC, Av. Luiz de Camões, 2090, CEP 88520-000, Lages, SC. E-mail: cassandro.amarante@udesc.br; cristiano.steffens@udesc.br

${ }^{4}$ Agronomists, Master Course students in Plant Production, CAV / UDESC, Av. Luiz de Camões, 2090, CEP 88520-000, Lages, SC. E-mail: thalitabeninca@hotmail.com; marcelapadilha76@gmail.com
} 


\section{INTRODUCTION}

The feijoa [Acca sellowiana (Berg.) Burret, synonymous Feijoa sellowiana (Berg.)], also known as pineapple guava, "goiabeira-serrana" (in Brazil) and "guayabo del pais" (in Uruguay), belongs to the Myrtaceae family and it is native to the Brazilian southern plateau and northeastern Uruguay (THORP; BIELESKI, 2002). In southern Brazil, the specie is well acclimated to wintry climates with occurrence predominating at altitudes above $800 \mathrm{~m}$ in wooded areas and in Araucaria forests (HICKEL; DUCROQUET, 2000). It is a shrub or small tree, which features ornamental characteristic by the elegance of blue-green canopy and beauty of its flowers, which can be used in urban or residential ornamentation. In addition to the fruits, the petals of the flowers can be consumed (decoration of dishes, salads, sweets) since they have a pleasant taste and intense color. The flowers consist of four to six fleshy petals, rose-colored in the inside and waxy on the outside, with scarlet stamens reaching up to $2 \mathrm{~cm}$ above the flower, and slightly thickened stigma (HICKEL; DUCROQUET, 2000; BELOUS et al., 2014).

In southern Brazil, the feijoa plant blossoms between October and January (DUCROQUET; HICKEL, 1991) and petal taste changes according to the different stages of anthesis (SAZIMA; SAZIMA, 2007). The flowers for direct or indirect (dish decoration) human consumption should be harvested at the time when the petals are entirely colored (wide open and exposing the numerous anthers and the stigma) (THORP; BIELESKI, 2002; DUCROQUET; HICKEL, 1991). With senescence, the petals of feijoa flowers lose their color, switching from intense rose to purple and, ultimately, turning white and not being appropriate anymore for consumption.

Birds feed on feijoa petals promoting flowers pollination (SAZIMA; SAZIMA, 2007), but little is known about the benefits of human consumption of the flowers. Flowers of many species are primarily used for therapeutical and/or medicinal purpose, such as Tropaeolum majus, Calendula officinalis, Rosa spp., Viola odorata, Viola tricolor, Taraxacum officinale, Sambucus nigra, Borago officinalis, Robinia pseudoaccacia, Malva sylvestris, Tagetes erecta, Cosmos sulphureus, Antigonon leptopus, Bouganvillea glabra, Salvia splendens, Camelia japonica, Bauhinia purpurea and Allamanda cathartica (SANGALLI et al., 2007; KAISOON et al., 2011; MLCEK; ROP, 2011; LI et al., 2014).

The flowers in general are highly perishable and longevity has a relevant role in determining their marketing value (MANSOURI, 2012). Shelf life of flowers can be extended by providing sugars (to replace carbohydrates consumed by the respiration) (ELHINDI, 2012), by refrigeration (to reduce physiological activity of tissues and pathogen development, consequently prolonging storage period) (MATTIUS et al., 2010), or by treatment with 1-methylcyclopropene (1-MCP, an inhibitor of ethylene action) (PIETRO et al., 2010).

Postharvest treatments with 1-MCP (PIETRO et al., 2010; KOU et al., 2012; BURANA et al., 2014), sucrose (SANGALLI et al., 2007; MONERUZZAMAN et al., 2010), ascorbic acid (SANGALLI et al., 2007) and salicylic acid (HATAMZADEH et al., 2012; BAHRAMI et al., 2013) have been applied to extend shelf life of cut flowers. However, as far as we know, there are no reports concerning the evaluation of such treatments to preserve feijoa flowers after harvest.

This study was carried out to evaluate the effects of different doses of sucrose, ascorbic acid, salicylic acid and 1-MCP on postharvest quality maintenance of feijoa flowers under refrigerated storage at $10 \pm 1{ }^{\circ} \mathrm{C}$ and $85 \pm 5 \% \mathrm{RH}$.

\section{MATERIALS AND METHODS}

Feijoa flowers were harvested at the germplasm bank located in the Estação Experimental de São Joaquim, from Empresa de Pesquisa Agropecuária e Extensão Rural (EPAGRI), state of Santa Catarina, southern Brazil (28 $8^{\circ} 6^{\prime} 40^{\prime \prime} \mathrm{S}$ and $49^{\circ} 56^{\prime} 09^{\prime \prime} \mathrm{W}$, at an altitude of $1.400 \mathrm{~m}$ ) in 2012 , in the early morning (between $8 \mathrm{~h}$ and $10 \mathrm{~h}$ ). Flowers recently opened (phenological stage F1) (DUCROQUET; HICKEL, 1991) were harvested, stored in trays containing water and immediately transported to the laboratory where the pedicels were cut to an uniform length.

The flowers were submitted to pulsing treatments with preservative solutions in polyethylene trays covered with transparent PVC film (total of four flowers/tray), with flowers pedicels maintained dipped in the preservative solutions of ascorbic acid, salicylic acid or sucrose, all of them at doses of 0 (control), 2, 5 and 10\%, for six hours at ambient conditions $\left(20 \pm 2{ }^{\circ} \mathrm{C}\right.$ and $\left.70 \pm 5 \% \mathrm{RH}\right)$. Subsequently, the pulsing solutions in the trays were replaced by distilled water (to avoid desiccation). The trays with the flowers were stored for 12 days at $10 \pm 1{ }^{\circ} \mathrm{C}$ (determined in a preliminary study as the most adequate temperature to preserve feijoa flower quality) and $85 \pm 5 \% \mathrm{RH}$.

For treatment with 1-MCP, the flowers were 
maintained in polyethylene trays covered with a transparent PVC film (total of four flowers/tray) with the pedicels in contact with distilled water. The flowers were exposed to 1-MCP $\left(\right.$ SmartFresh $\left.^{\circledR}\right)$ in 7.6 L hermetic chambers for six hours at ambient condition $\left(20 \pm 2{ }^{\circ} \mathrm{C}\right.$ and $\left.70 \pm 5 \% \mathrm{RH}\right)$, at concentrations of 0 (control), 250, 500 and 1,000 $\mathrm{nL} \mathrm{L}^{-1}$. After treatment with 1-MCP, the trays with the flowers were stored for 12 days at $10 \pm 1{ }^{\circ} \mathrm{C}$ and $85 \pm 5 \%$ RH.

Six hours after the pulsing with the preservative solutions and treatment with 1-MCP, regarded as day zero of storage, flowers all the treatments received the first visual quality evaluation, as well as at every two days for up to 12 days of storage. Flowers were assessed for color, wilting and darkening of the petals with a hedonic scale varying from 1 to 5. Color was assessed on the adaxial (upper) face considering the following scale: 1) $100 \%$ pink; 2) $50 \%$ pink and $50 \%$ purple; 3) $100 \%$ purple; 4) $50 \%$ purple and $50 \%$ white and 5) $100 \%$ white. Wilting and darkening of the petals were assessed considering the following scores: 1 ) none; 2) up to $25 \%$ of the petals with symptoms; 3 ) $26 \%$ to $50 \%$ of the petals with symptoms; 4) $51 \%$ to $75 \%$ of the petals with symptoms; and 5) more than $76 \%$ of the petals with symptoms.

Each trial with preservative solutions or 1-MCP treatment was considered a distinct experiment. The experiments followed a completely randomized design, with four replicates, each replicate with four flowers. Data were submitted to analysis of variance (ANOVA) with the SAS software (SAS INSTITUTE, 2002), and treatment means were compared by the Tukey's test $(\mathrm{p}<0.05)$.

\section{RESULTS AND DISCUSSION}

Flowers quality loss generally involves wilting, darkening, lesion caused by fungal infections and collapse/necrosis of petal tissues. At the beginning of the trials (day zero), petals exhibited a natural variation in color, but all treatments were scored as 1 for wilting and darkening of the petals (Figures 1 to 4 ).

Changes in feijoa petals color are indicative of postharvest quality losses. Flowers are inappropriate for consumption after reaching a petal color close to white.

Sucrose and ascorbic acid treatments did not delay changes of petals color in comparison to the control (Figures 1A and 2A).

Treatment with salicylic acid, regardless of concentration, delayed petal color change up to the sixth day of storage in comparison to the control (Figure 3A). In lysianthus, salicylic acid treatments prolonged flower quality by maintaining high activity of peroxide dismutase and reducing the activity of lipoxygenase (the enzyme that promotes lipid peroxidation), thus maintained color and turgidity of the flowers (BAHRAMI et al., 2013). Therefore, color preservation in feijoa petals treated with salicylic acid might be related to the preservation of tissue antioxidant system.

Treatment with 1-MCP at $500 \mathrm{~nL} \mathrm{~L}^{-1}$ delayed petal color change for up to eighth day of storage in comparison to the control (Figure 4A). In roses cv. Vega, 1-MCP at $500 \mathrm{~nL} \mathrm{~L}^{-1}$ prolonged the red color of the petals and shelf life of the flowers for up to 19 days (PIETRO et al. 2010). Color change of the petals in flowers is affected by the presence of either endogenous or exogenous ethylene. Therefore, 1-MCP binding to ethylene receptor inhibits the action of the phytohormone, delaying color changes of the petals.

Feijoa petals have an intense rose color (BELOUS et al., 2014), which is an important visual characteristic to take in account since vivid and bright colors are preferred by the consumers, and loss of color devaluate the product quality. According to Mlcek and Rop (2011), sensorial attributes such as size, aroma and color are the key quality criteria of edible flowers. According to the authors, anthocyanin and carotenoid produce vibrant colors, and these components have a high correlation with antioxidant activity in flowers.

Treatments with salicylic acid, ascorbic acid and 1-MCP delayed wilting of feijoa petals (Figures 2B,3B and 4B).

Salicylic acid at 2, 5 or $10 \%$ had the most significant effect to reduce petal wilting in comparison to the control along the entire evaluation period (Figure 3B). Flowers treated with salicylic acid had wilting score 2 after six days of storage when treated with doses of $5 \%$ or $10 \%$, and after eight days when treated with $2 \%$, while the control had score 2 on the fourth day.

The content of salicylic acid increases in the tissues under stress, and this compound acts as a signaling molecule inducing a series of reactions inherent to the defense systems in plants, triggering physiological responses such as increments in the activity of cyanide resistant oxidase (CRO) in the electron transport chain. The CRO is active when electron flow across the conventional electron chain is constrained by impairment of cytochrome $c$ oxidase (cyanide sensitive) activity. CRO also reduce reactive oxygen species (ROS) formed when the 
tissues are under stress (NIE et al., 2015).

Salicylic acid also retards senescence in some plant species by the inhibition of ethylene biosynthesis and/or ethylene action, suppressing the activities of ACC synthase and ACC oxidase (HATAMZADEH et al., 2012). Salicylic acid also reduces dehydration and respiratory activity, therefore reducing fresh weight losses of cut flowers. According to Hatamzadeh et al. (2012), pulsing with $0.15 \%$ salicylic acid reduced water loss and delayed senescence of gladiolus flower stalks. In chrysanthemum, salicylic acid at low concentrations $(0.01 \%$ and $0.1 \%)$ prolonged vase life by preserving membrane stability and reducing lipid peroxidation (MANSOURIS, 2012). Similar effect of low fresh weigh loss was reported in anthurium cv. Cheers also treated with low doses of salicylic acid and stored at $4{ }^{\circ} \mathrm{C}$ (PROMYOU et al., 2012).

In feijoa flowers, the wound caused by the harvest and their storage at low temperature represent a stress condition, and the exogenous supply of salicylic acid might potentialize the CRO activity, keeping cellular homeostasis and therefore delaying senescence.

Treatments with 1-MCP at the doses of 500 and $1,000 \mathrm{~nL} \mathrm{~L}^{-1}$ delayed petal wilting, with scores remaining below 2 for up to the fourth day of storage (Figure 4B). PIETRO et al. (2010) reported similar results, with reduced fresh weight loss and preservation of flower turgidity in roses treated with $1-\mathrm{MCP}$ at $500 \mathrm{~nL} \mathrm{~L}^{-1}$. According to Hastenreiter et al. (2006), turgescence is required for bud flower development and to maintain flower metabolic activity after harvest.

In carnations and snapdragons, the combined effects of treatment with 1-MCP and storage under modified atmosphere (MA) reduced fresh weight loss during 14 days of storage at $5{ }^{\circ} \mathrm{C}$ (KOU et al., 2012). This was attributed to the reduction of ethylene action and respiration as result of the lower partial pressure of oxygen and higher partial pressure of carbon dioxide under MA.

Treatments with ascorbic acid at the doses of $2 \%$ and $5 \%$ delayed feijoa petal wilting up to the sixth day of storage (Figure 2B). The most noticeable petal wilting delay during this period was achieved at the dose of 5\%, with wilting score below 3 . Bedour and Rawia (2011) reported preservation of relative water content and prolonged vase life of gladiolus treated with ascorbic acid at $0.2 \%$. Ascorbic acid is an enzymatic cofactor, an antioxidant and an electron donor/receptor at the plasmalemma and internal membrane of chloroplasts. High endogenous levels of ascorbic acid support the antioxidant system and protects the tissues from oxidative damages (CHERUTH, 2009).

Treatments with sucrose did not prevent petal wilting, and even increased wilting at the highest doses of $5 \%$ and $10 \%$ in comparison to the control (Figure 1B). Treatment with sucrose might have no effect or even can cause an adverse effect on flowers quality preservation (SANGALLI et al., 2007). In flower of Viburnum tinus, the treatment with sucrose at doses of $1-2 \%$ plasmolyzed the cells and caused collapse of flower tissues (DARRAS et al., 2010). Therefore, future work should test lower doses of sucrose $(<2 \%)$ to preserve feijoa flowers without affecting the water relations in the petals.

Treatments with sucrose, ascorbic acid and salicylic acid did not delay darkening of petals in comparison to the control (Figures 1C, 2C, and 3C). Feijoa flowers treated with ascorbic acid and sucrose (regardless of doses) had higher petal darkening scores in comparison to the control until the fourth and eighth days of storage, respectively. Only 1-MCP at $500 \mathrm{~nL} \mathrm{~L}^{-1}$ delayed petal darkening until the fourth day of storage. Similar results were reported by Pietro et al. (2010), with roses treated with 1-MCP at 250 and $500 \mathrm{~nL} \mathrm{~L}^{-1}$.

Petal darkening might be caused by several factors, such as oxidation of phenolic compounds (especially anthocyanins), water stress (PIETRO et al., 2012) and electrolyte leakage (PHETSIRIKOON et al., 2012). Electrolyte leakage results from ethylene action impairing membrane selective permeability after harvest, leading to darkening of tissues caused by the action of polyphenoloxidases (PPOs) on polyphenols, and finally cell death (PHETSIRIKOON et al., 2012).

1-MCP might reduce electrolyte leakage. Snapdragons and carnations stored under MA and treated with 1-MCP had lower electrolyte leakage after 14 days of storage in comparison to the control and to flowers stored under MA without treatment with 1-MCP (KOU et al., 2012). In inflorescences of Dendrobium stored at $5{ }^{\circ} \mathrm{C}$, the treatment with 1-MCP at $100 \mathrm{~nL} \mathrm{~L}^{-1}$ reduced electrolyte leakage in flower buds as well in open flowers.

Flower petals have a high surface/volume ratio and therefore are highly sensitive to dehydration (KOU et al., 2012). The treatment with 1-MCP at $500 \mathrm{~nL} \mathrm{~L}^{-1}$ was the most effective to preserve cell turgidity and therefore delaying petal darkening by reducing water stress. Positive effects of 1-MCP in darkening delay might be also associated to the reduction of phenolic compounds oxidation, which takes place under stress conditions (DOORN; WOLTERING, 2008). 

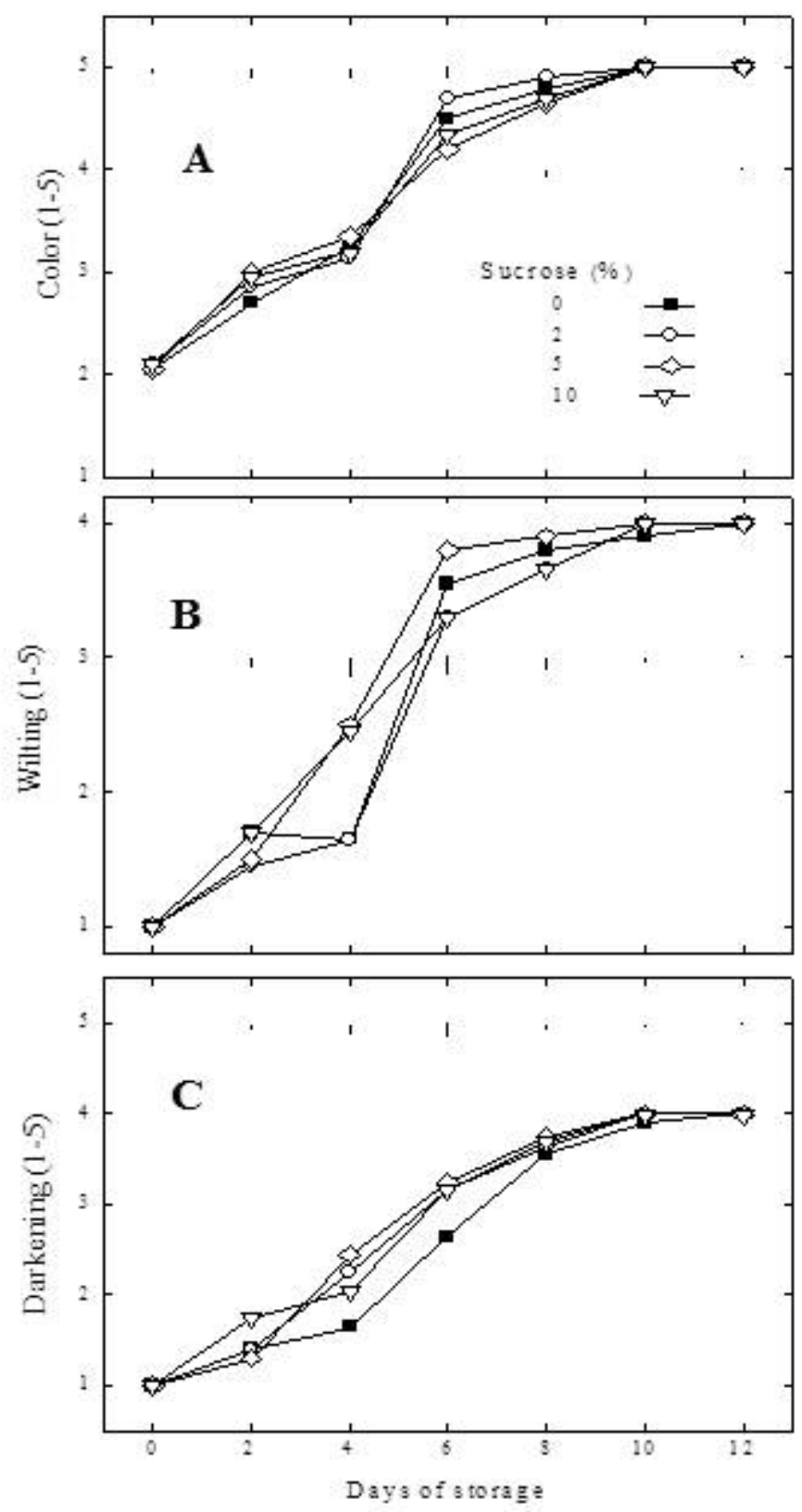

FIGURE 1-Effects of different concentrations of sucrose on color (A), wilting (B) and darkening (C) of feijoa petals during refrigerated storage at $10 \pm 1{ }^{\circ} \mathrm{C} / 85 \pm 5 \% \mathrm{RH}$. Bars inside the figure indicate minimal significative differences calculated by Tukey's test $(p<0.05)$. 

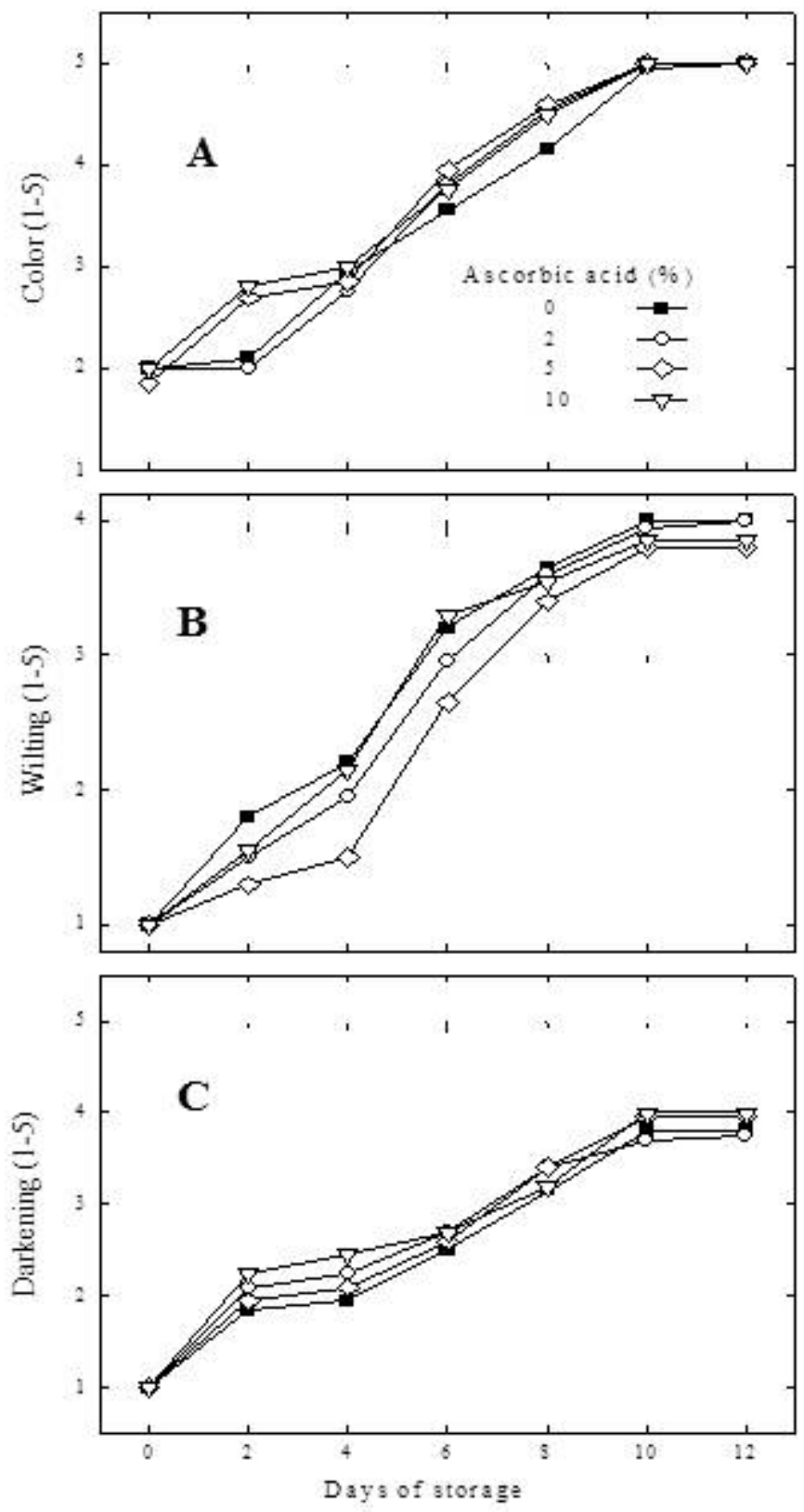

FIGURE 2- Effects of different concentrations of ascorbic acid on color (A), wilting (B) and darkening (C) of feijoa petals during refrigerated storage at $10 \pm 1{ }^{\circ} \mathrm{C} / 85 \pm 5 \% \mathrm{RH}$. Bars inside the figure indicate minimal significative differences calculated by Tukey's test $(p<0.05)$. 

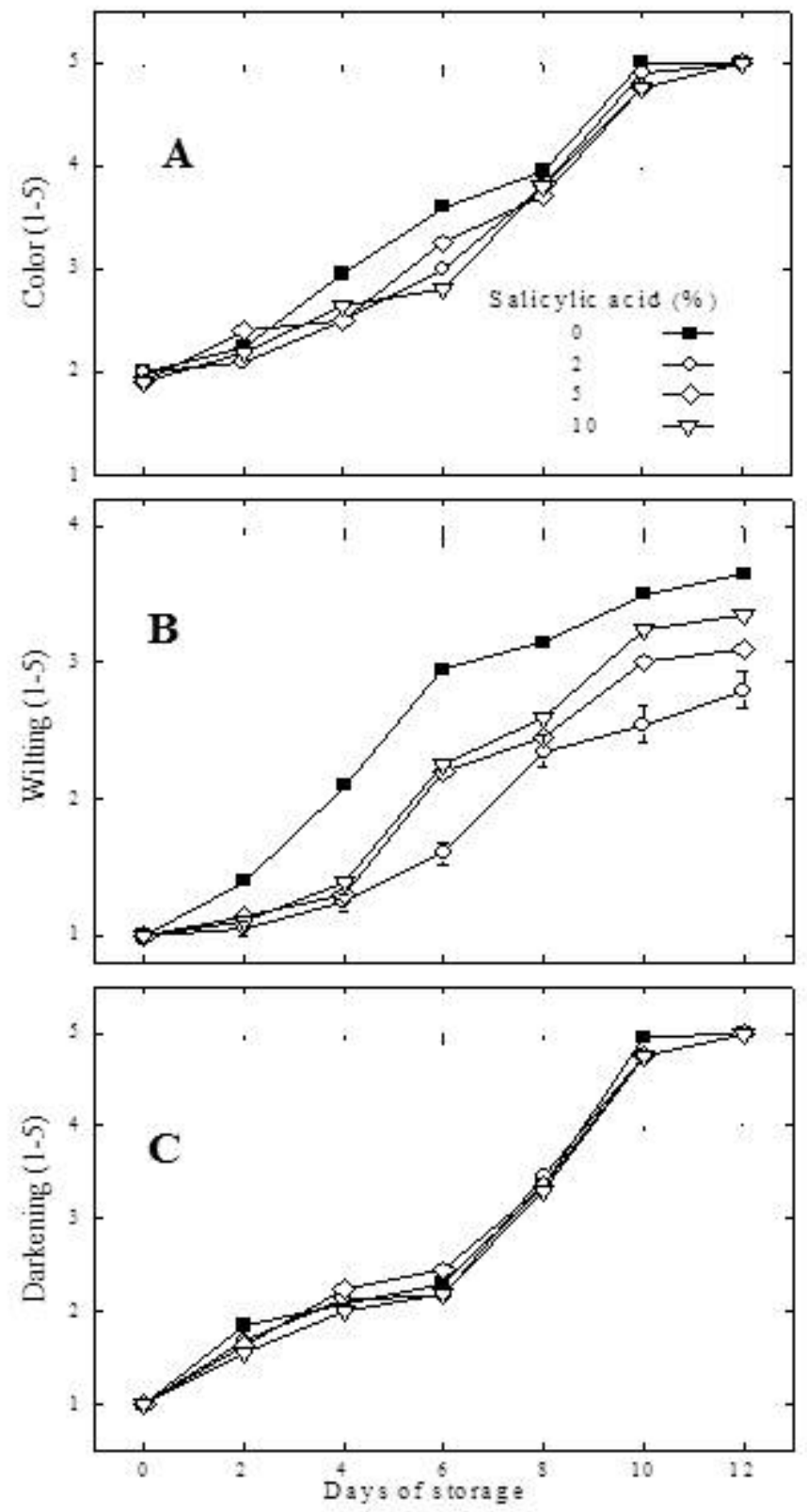

FIGURE 3-Effects of different concentrations of salicylic acid on color (A), wilting (B) and darkening (C) of feijoa petals during refrigerated storage at $10 \pm 1{ }^{\circ} \mathrm{C} / 85 \pm 5 \% \mathrm{RH}$. Bars inside the figure indicate minimal significative differences calculated by Tukey's test $(p<0.05)$. 

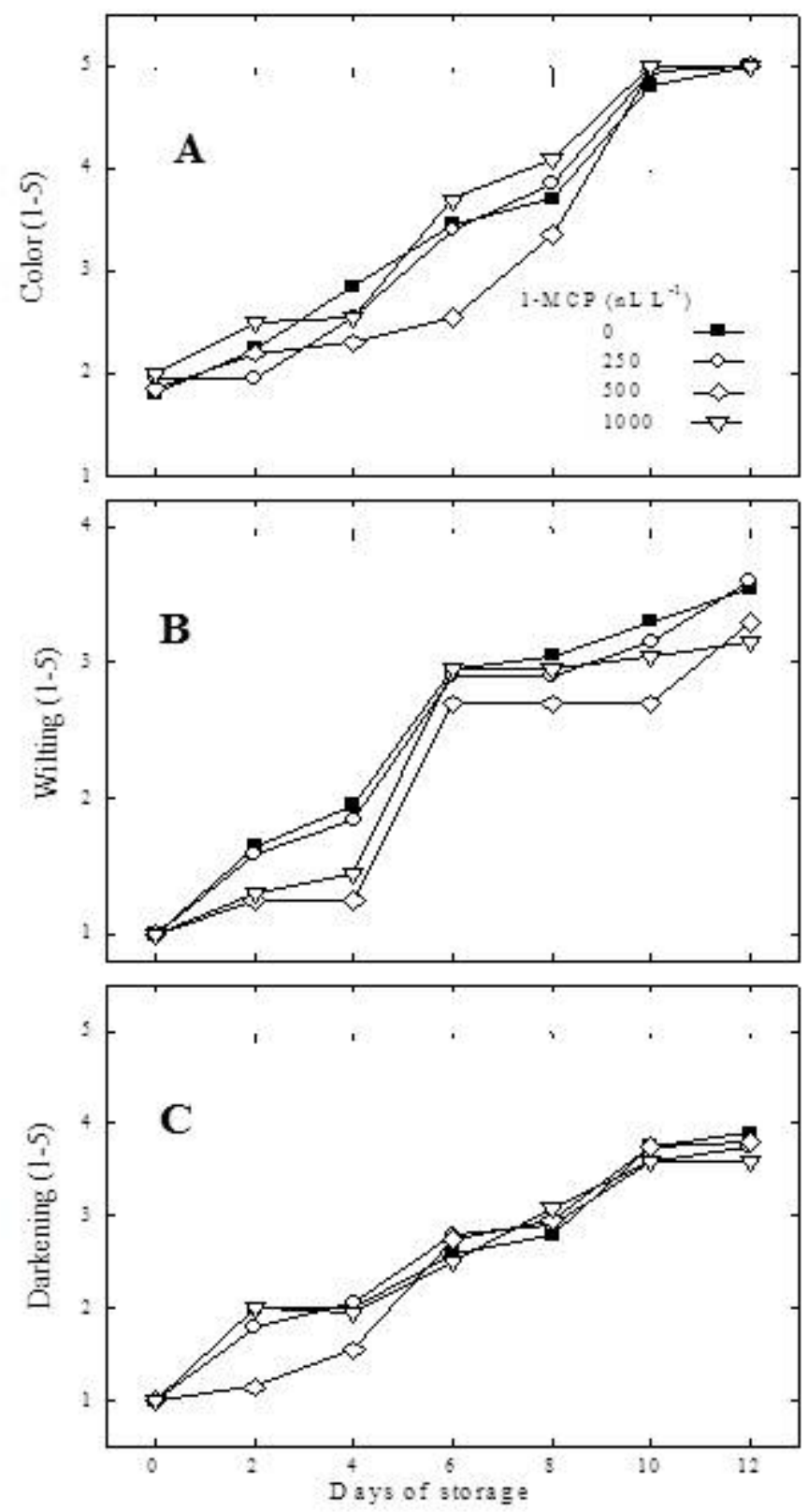

FIGURE 4-Effects of different concentrations of 1-MCP on color (A), wilting (B) and darkening (C) of feijoa petals during refrigerated storage at $10 \pm 1{ }^{\circ} \mathrm{C} / 85 \pm 5 \% \mathrm{RH}$. Bars inside the figure indicate minimal significative differences calculated by Tukey's test $(p<0.05)$. 


\section{CONCLUSIONS}

Feijoa flowers treated with $1-\mathrm{MCP}$ at $500 \mathrm{~nL}$ $\mathrm{L}^{-1}$ and salicylic acid at 2, 5 and $10 \%$ have a better preservation of petals rose color during cold storage. Treatments with salicylic acid at 2\%, 1-MCP at 500 $\mathrm{nL} \mathrm{L} \mathrm{L}^{-1}$, and ascorbic acid at $5 \%$ delay feijoa petal wilting during cold storage. The treatment with $1-\mathrm{MCP}$ at $500 \mathrm{~nL} \mathrm{~L}^{-1}$ is the most effective to delay petal darkening of feijoa flowers.

\section{ACKNOWLEDGEMENTS}

The authors thank the National Council for Scientific and Technological Development (CNPq), the Santa Catarina State Rural Extension and Agricultural Research Enterprise (EPAGRI)/ Experimental Station of São Joaquim, and the Federal Institute of Santa Catarina, for financial support of this research.

\section{REFERENCES}

BAHRAMI, S.N.; ZAKIZADEH, H.; HAMIDOGHLI, Y.; GHASEMNEZHAD, M. Salicylic acid retards petal senescence in cut lisianthus (Eustoma grandiflorum 'Miarichi Grand White') flowers. Horticulture, Environment and Biotechnology, North Jeolla Province, v.54, n.6, p.519-523, 2013.

BEDOUR, A.A.; RAWIA, A.E. Improving gladiolus growth, flower keeping quality by using some vitamin aplication. Journal of American Science, New York, v.7, n.3, p.169-174, 2011.

BELOUS, O.; OMAROV, M.; OMAROVA, Z. Chemical composition of fruits of a feijoa (Feijoa sellowiana) in the conditions of subtropics of Russia. Scientific Journal for Food Industry, Nitrianske Hrnčiarovce, v.8, n.1, p.119-123, 2014.

BURANA, C.; KUROKURA, T.; YAMAKI, Y.; YAMANE, K. Modified atmosphere (MA) and 1-methylcyclopropene (1-MCP) combination treatment extends the postharvest life of carnations. Environmental Control in Biology, Tokyo, v.52, n.3, p.131-136, 2014.

CHERUTH, A.J. Changes in non enzimatyic anti oxidation and ajmalicine production in Catharanthus roseus with different soil salinity regimes. Botany Research International, Dubai, v.2, n.1, p.1-6, 2009.
DARRAS, A.I.;AKOUMIANAKI-IOANNIDOU,A.; POMPADAKIS, N.E. Evaluation and improvement of pos-harvest performanceof cut Viburnun tinus inflorescence. Scientia Horticulturae, Amsterdam, v.124, n.2, p.376-380, 2010.

DOORN, W.G.V.; WOLTERING, E.J. Physiology an molecular biology of petal senescence. Journal of Experimental Botany, Oxford, v.59, n.3, p.453480, 2008.

DUCROQUET, J.P.H.H.; HICKEL, E.R. Fenologia da goiabeira serrana (Feijoa sellowiana Berg) no Alto Vale do Rio do Peixe. Revista Brasileira de Fruticultura, Jaboticabal, v.13, n.3, p.313-321, 1991.

ELHINDI, K.M. Evaluation of several holding solutions for prolonging vase-life and keeping quality of cut sweet pea flowers (Lathyrus odoratus L.). Saudi Journal of Biological Science, Riyadh, v.19, n.2, p.195-202, 2012.

HASTENREITER, A.F.; VIEIRA, Z.G.J.; FARIA, T.R.; Longevidade pós-colheita de flores de Oncidium varicosum (Orchidaceae). Ciências Agrárias, Londrina, v.27, n.1, p.27-34, 2006.

HATAMZA DEH, A.; HATAMI, M. ; GHASEMNEZHAD, M. Efficiency of salicylic acid delay petal senescence and extended quality of cur spikes of Gladiolus grandiflora cv. "wing's sensation". African Journal of Agricultural Research, Nairobi, v.7, n.4, p.540-545, 2012.

HICKEL, E. R.; DUCROQUET, J. P. J. Polinização entomófila da goiabeira serrana, Feijoa sellowiana (Beg), em Santa Catarina. Revista Brasileira de Fruticultura, Jaboticabal, v.22, n.1, p.96-101, 2000.

KAISOON, O.; SIRIAMORNPUN, S.; WEERAPREEYAKUL, N.; MEESO, N. Phenolic compounds and antioxidant activities of edible flowers from Thailand. Journal of Functional Foods, Dallas, v.3, n.2, p.88-99, 2011.

KOU, L.; TURNER, E.R.; LUO, Y. Extending the shelf life of edible flowers with controlled release of 1-methylcyclopropene and modified atmosphere packaging. Journal of Food Science and Technology, Mysore, v.77, n.5, p.188-193, 2012. 
LI, A.; LI, S.; LI, H.; XU, D.; XU, X.; CHEN, F. Total phenolic contents and antioxidant capacities of 51 edible and wild flowers. Journal of Functional Foods, Dallas, v.6, n.1, p.319-330, 2014.

MANSOURI, H. Salicylic acid and sodium nitroprusside improve postharvest life of Chrysanthemums. Scientia Horticulturae, Amsterdam, v.145, n.2, p.29-33, 2012.

MATTIUZ, C.F.M.; RODRIGUES, T.J.D.; MATTIUZ, B.; MARTINS, R.N. Armazenamento refrigerado de inflorescências cortadas de Oncidium varicosum 'Samurai'. Ciência Rural, Santa Maria, v.40, n.11, p.2289-2293, 2010.

MLCEK, J.; ROP, O. Fresh edible flowers of ornamental plants - A new source of nutraceutical foods. Trends in Foods Science \& Technology, Amsterdam, v.22, n.10, p.561-569, 2011.

MONERUZZAMAN, K.M; HOSSAIN, A.B.M.S.; AMRU, N.B.; SAIFUDIN, M.; IMDADUL, H.; WIRAKARNAIN, S. Effect of sucrose and kinetin on the quality and vase life of Bougainvillea glabra var. Elizabeth Angus bracts at different temperatures. Australian Journal of Crop Science, Inala, v.4, n.7, p.474-479, 2010.

NIE, S.; YUE, H.;ZHOU, J.; XING, D. Mitochondrialderived reactive oxygen species play a vital role in the salicylic acid signaling pathway in Arabidopsis thaliana. PloS ONE, San Francisco, v.10, n.3, p.125, 2015.

PHETSIRIKOON, S.; KETSA, S.; DOORN, W.G. VAN. Chilling injury in Dendrobium inflorescences is alleviated by 1-MCP treatment. Postharvest Biology and Technology, Amsterdam, v.67, n.1, p.144-153, 2012.
PIETRO, J. de; MATTIUZ, B.; MATTIUZ, C.F.M. Influência do 1-MCP na conservação pós-colheita de rosas cv. Vega. Ciência e Agrotecnologia, Lavras, v.34, n.5, p.1176-1183, 2010.

PIETRO, J. de; MATTIUZ, B.; MATTIUZ, C.F.M.; RODRIGUES, T.J.D. Qualidade de rosas de corte tratadas com produtos naturais. Ciência Rural, Santa Maria, v.42, n.10, p.1781-1788, 2012.

PROMYOU, S.; KETSA, S.; DOORN, W.G.V. Salicylic acid alleviates chilling injury in anthurium (Anthurium andraeanum L.) flowers. Postharvest Biology and Technology, Amsterdam, v.64, n.1, p.104-110, 2012.

SANGALLI, A.; SCALON, S. de P.Q.; CARVALHO, J.C.L. de. Perda de massa de flores de capuchinha após armazenamento. Horticultura Brasileira, Brasília, v.25, n.3, p.471-474, 2007.

SAZIMA, I.; SAZIMA, M. Petiscos florais: pétalas de Acca sellowiana (Myrtaceae) como fonte alimentar para aves em área urbana no Sul do Brasil. Biota Neotropica, São Paulo, v.7, n.2, p.307-311, 2007.

THORP, T. G.; BIELESKI, R. L. Feijoas: origins, cultivation and uses. New Zealand: David Bateman Publishing, 2002. $87 \mathrm{p}$. 